\title{
Criações e usos das Artes como tecelãs de "conhecimentossignificações" curriculares
}

\section{Creations and uses of Arts as weavers of curricular "knowledge-meanings"}

\section{Creaciones y usos de las Artes como tejedoras de los "conocimientossignificaciones" curriculares}

\author{
Noale Toja ${ }^{1}$ \\ Rafaela Rodrigues da Conceição ${ }^{1}$ \\ Talita Malheiros ${ }^{1}$
}

DOI: http://dx.doi.org/10.20435/serie-estudos.v26i58.1603

\begin{abstract}
Resumo: Este texto é um apanhado de criações, cocriações, afetos, afecções e relações entre artes, mundos, vivências, experiências, memórias e conhecimento. Apontando para a multiplicidade de existências possíveis através das imagens e dos sons, apresentaremos neste trabalho algumas criações que conferem às artes novas possibilidades de "praticarpensar"2 o currículo escolar e tessituras de "conhecimentossignificações" improváveis e singulares nos "dentrofora" das escolas, lançando mão da arte como um caminho de sensibilidade e afetações nas redes educativas que formamos e que nos formam. A arte como manifestação criativa humana e intrínseca aos fenômenos culturais, quando articulada aos componentes curriculares, acessa as transversalidades entre as diferentes áreas de conhecimentos, diante da pedagogia de sons, de cheiros, de imagens, gostos e gestos. Como narrativas, nos ajudam a expressar e criar outras maneiras de compreensão do mundo vivido, dialogando de forma ética, estética e política com os "praticantespensantes" dos cotidianos e "espaçostempos" escolares.
\end{abstract}

Palavras-chave: artes; criação; redes educativas.

Abstract: This text is a collection of creations, co-creations, affections, and relations between arts, worlds, experiences, memories, and knowledge. Pointing to a multiplicity of possible existences through images and sounds, we'll present in this work some creations that give arts new possibilities to 'practice-think' the school curriculum and improbable and singular textures

\footnotetext{
${ }^{1}$ Universidade do Estado do Rio de Janeiro (UERJ), Rio de Janeiro, Rio de Janeiro, Brasil.

${ }^{2}$ As autoras utilizam a escrita de palavras unidas, em itálico e entre aspas simples, porque consideram que as dicotomias limitam o desenvolvimento da sua corrente de pesquisa. Por vezes, algumas palavras aparecem invertidas em relação ao modo como são ditas para mostrar a multiplicidade dos cotidianos com os quais vivemos, nos formamos e pesquisamos.
} 
of 'knowledge-meanings' in 'inside-outside' of schools, making use of arts as a way of sensitivity and affectations in educational networks that we form and that form us. Art as a creative human expression and intrinsic to cultural phenomena, when articulated to curricular components, it accesses transversalities between different areas of knowledge related to the pedagogy of sounds, smells, images, tastes, and gests. As narratives, they help us to express and create other ways of understanding the lived world, dialoguing ethically, aesthetically, and politically with "practitionersthinking" of schools' daily life and "spaces-times".

Keywords: arts; creations; educational networks.

Resumen: Este texto es un repaso de creaciones, co-creaciones, afectos, afecciones y relaciones entre artes, mundos, vivencias, experiencias, memorias y conocimientos. Apuntando a la multiplicidad de existencias posibles a través de imágenes y sonidos, presentaremos en este trabajo algunas creaciones que dan a las artes nuevas posibilidades para "practicarpensar" el currículo escolar y texturas de "conocimientossignificaciones" improbables y singulares en el "dentrofuera" de las escuelas, haciendo uso del arte como vía de sensibilidad y afectaciones en las redes educativas que formamos y que nos forman. El arte como expresión creativa humana e intrínseca a los fenómenos culturales, cuando se articula a componentes curriculares, accede a las transversalidades entre diferentes áreas del conocimiento, frente a la pedagogía de los sonidos, los olores, las imágenes, los gustos y los gestos. Como narrativas, nos ayudan a expresar y crear otras formas de entender el mundo vivido, dialogando ética, estética y política con los "practicantespensantes" de los cotidianos y "espaciotiempos" escolares.

Palabras clave: artes; creación; redes educativas.

\section{AS ARTES DAS CRIAÇÕES COM IMAGENS E SONS}

Num mundo pandêmico (2020-2021), em que experienciamos as relações, o trabalho, o estudo, a doutrinação, os afetos e a arte enquadrados nos ambientes das telas, somos atravessados por imagens e sons, fabricando e consumindo de maneira híbrida, seja síncrona, seja assíncrona, em "espaçostempos" virtuais, como Certeau (2014) vai anunciar como 'uso', que é o que nos interessa, ao pesquisar as relações de imagens e sons na 'discênciasdocências' e seus usos.

Imagens e sons são elementos nômades que percorrem de um ponto a outro como dados em pixels, ondas e em linhas invisíveis da virtualidade. Transcendem os aspectos demonizantes, para ziguezaguear como artefatos de comunicação, de publicidade, de comportamentos, pensamentos e ações, hegemônico de criações de verdades, de representações de realidades, como também de criação de singulares manifestações íntimas e plurais de um indivíduo ou de um coletivo.

Tão logo uma imagem ou um som, ao serem criados, trazem rastros, impressões de pensamentos e marcas de uma cultura que mobilizam uma ideia de "verdade". Podemos perceber essas impressões como reproduções de padrões, 
ou decalques (DELEUZE; GUATTARI, 2007) habitando no imaginário, criando as crenças, como fabulações, narrativas de segmentos de imagens e sons, que fragmentam e estereotipam comportamentos, criando os clichês, que ao mesmo tempo nos capturam.

Ao pensarmos nas artes em sua potência de agenciamento de formas outras de "sentirpensaragir", em se relacionar com os acontecimentos do mundo, podemos dizer que ela nos desloca por terras muitas vezes não planejadas ou já ocupadas? Como pensar e criar com imagens e sons num território, com suas fronteiras definidas, ou num ambiente deslizante, tão complexo que são os "espaçostempos" escolares? Talvez essa máquina de guerra que nos conduz a "sentimentospensamentos" singulares possam nos oferecer pistas desse possível entrelaçamento entre subjetividades, docência, memórias, histórias e signos artísticos.

A arte como um acontecimento, como movimentos nômades de afetações, causa deslocamentos, apropriações e relações, de maneiras singulares em cada um. Isso reflete nos trabalhos trazidos pelos 'discentesdocentes', com os que tecemos fabulações nas nossas redes educativas.

Fazendo uso de artefatos tecnológicos digitais, criamos filmetes, podcasts, livros de literatura, cartões-postais, aproximando-nos mais intensamente de nossas pesquisas, tramando pelas artes a sensibilização às questões que emergem nos cotidianos da pesquisa. Na potência do falso ou de criação, na potência do desejo, criamos, nos diferentes "espaçostempos", modos de existir, informações genéricas e específicas, que geram sensações de excessos e de ausências.

\section{POTÊNCIA DO FALSO, POTÊNCIA DE CRIAÇÃO}

Mas, de fato, o que é realidade? Será que realmente as imagens e os sons criados, produzidos, são representações de realidades, ou fabulações nas criações na potência do falso?

Questionamos, desde a antiguidade, acerca da potência da criação imagética e imaginativa, como um ambiente da não verdade, escapando da ideia de idolatria, ou como uma criação de realidade absoluta. A história ocidental da humanidade estruturou-se numa cultura de dominação a partir de dogmas, pensamentos e comportamentos doutrinadores. Inculcar as venerações e as ilusões em torno do conceito de uma única verdade era urgente para as dominações dos corpos e 
espíritos, sob o paradigma do medo e do poder onipresente, na ideia de um único criador. Assim, colocar nas mãos de sujeitos ordinários a potência de criação de realidades pode causar ameaças para sistemas pautados em verdades absolutas e no poder onipresente da razão.

Ao pensar na potência do falso, trazido por Nietzsche e trabalhado como personagem conceitual por Deleuze e Guattari (1993), em que, para Nietzsche, é a dúvida acerca da verdade absoluta de um deus único e de uma única razão, Deleuze e Guattari vão além, para desconfiar de tudo que é dado como realidade, partindo da ideia de uma potência de vontade, que, em si, é a própria potência criadora, o que Nietzsche traz como potência do falso, numa ideia da morte de Deus, ou de uma verdade única. Deleuze traz o poder da criação de realidades, a partir da crença de cada um e do desejo mobilizador, como uma máquina de guerra. Dessa forma, nem para Nietzsche, nem para Deleuze, potência do falso é uma mentira, uma idolatria, uma representação falsa; ela é uma potência imaginativa, criadora de imagens e sons e gestos que revelam suas fabulações e, com isso, tornam-se realidades. Neste sentido, percebemos o perigo em reduzir eventos, acontecimentos, situações, vivências, numa ideia de uma realidade única, pois são enunciados, agenciamentos, experiências vividas por muitos, e cada um, na sua singularização, ou individuação, vai perceber, sentir em seu processo de subjetivação com suas afetações.

\section{HERESIA IMAGÉTICA}

A história das imagens nos conta que estas sempre foram associadas às atividades clandestinas, marginais e, por vezes, proibidas ou ligadas aos rituais mágicos, ilusionistas ou à idolatria. Machado (2001) nos explica que na Grécia Antiga as imagens não foram proibidas, mas o artista plástico se assemelhava a um impostor ao imitar a aparência das coisas sem ter o domínio da ciência e da verdade delas. Ou seja, um objeto pintado em um quadro era apenas uma representação infiel de sua aparência externa, e não o objeto real, com suas funcionalidades, utilização ou processo de confecção.

A imagem, conclui Platão, pode se parecer com a coisa representada, mas não tem a sua realidade. É uma imitação de superfície, uma mera ilusão de ótica, que fascina apenas as crianças e os tolos, os destituídos de razão. O pintor, portanto, produz um simulacro [eidolon, de onde deriva a nossa 
palavra ídolo], ou seja, uma representação falsa, uma representação do que não existe ou do que não é verdade, engodo, imagem [eikon] destituída de realidade, como as visões do sonho e do delírio, as sombras projetadas no chão ou nos reflexos na água. Nesse sentido, a atividade do pintor é charlatanice pura e o culto dos simulacros [eidolon latreia, de onde deriva idolatria] a forma não religiosa da idolatria. (MACHADO, 2001, p. 9-10).

Esse mesmo autor afirma que o segundo interdito das imagens teria acontecido durante o Império Bizantino (séculos VIII e IX) "[...] quando a produção, a disseminação e o culto das imagens foram proibidos" (MACHADO, 2001, p. 10), o que levou os adeptos da iconofilia e da iconolatria à perseguição e execução, além da destruição e queima de quadros em praça pública.

A terceira interdição ocorreria novamente com a Reforma Protestante, já na Idade Média (século XVI). Todos aqueles que prestavam culto às imagens ou às esculturas eram considerados idólatras pelas igrejas, que não admitiam nenhuma representação em seus templos ou nas casas dos devotos. Ainda na modernidade alguns meios de comunicação, como a televisão e o cinema, também eram temidos como grandes interferentes na vida e nas ações cotidianas de ortodoxos, protestantes e católicos. E isso perdurou até a primeira metade do século XX.

Esses ciclos que caracterizam a pintura e a escultura como vãs e colocam as imagens como uma produção irracional e destinada à contemplação dos analfabetos e ignorantes fazem com que a palavra escrita seja considerada a única "fonte da verdade" até os tempos modernos. A palavra então era superior à mera impressão física ou aparência das coisas, assemelhando-se à razão e instaurando uma superioridade nobre àqueles que eram letrados.

Com a chegada da pós-modernidade, as imagens começam a ocupar espaços e circular em nossas vidas cotidianas, lares e lugares inimagináveis, subtraindo a hegemonia da escrita e anunciando um novo analfabetismo. É certo que os computadores, em especial, incrementaram novas formas de ler e escrever e vieram para validar ainda mais a palavra escrita. Mas o desenvolvimento dos meios audiovisuais têm nos mostrado que as imagens e os sons estão se impondo fortemente como uma forma de comunicação e pensamento mais acessível que o texto escrito.

[...] a imagem é uma forma de construção do pensamento tão sofisticada que sem ela provavelmente não teria sido possível o desenvolvimento das ciências como a biologia, a geografia, a geometria, a astronomia e a medicina. 
Não por acaso, o cientista, tal como o artista plástico, sempre foi uma espécie de afásico: ele fala e escreve pouco, usa uma linguagem extremamente condensada, mas se expressa de forma extremamente condensada, mas se expressa de forma extraordinariamente eloquente através de diagramas estruturais. (MACHADO, 2001, p. 23-4).

Hoje, é inegável o papel estruturante e constitutivo das imagens no mundo científico, artístico, militante, corporativo, virtual e educativo. Aprendemos não somente a conviver com as imagens, mas pensar, criar e resistir com elas, tornando nossas ações cotidianas e narrativas mais complexas e múltiplas.

\section{IMAGENS E SONS NÔMADES - DESLOCAMENTOS DE RETERRITORIALIZAR PARA DESTERRITORIALIZAR}

Tomando o clichê (GUÉRON, 2011) como padronizador nos modos de fazer arte, ao criar nossas peças artísticas no grupo de pesquisa junto aos "discentesdocentes", reproduzimos a forma, repetimos as receitas, num processo de reterritorialização no ambiente educativo. Porém, mesmo na repetição das formas e padrões, é possível criar outras linhas e superfícies deslizantes, que deslocam entre uma coisa e outra, permitindo a coexistência, ao mesmo tempo em que se ensaia desterritorializar, escapando das próprias receitas e normas, pelas inquietações e afetos que vão sendo enredadas pelos "praticantespensantes" em seu plano de imanência.

No movimento das pesquisas com os cotidianos, nós nos encontramos nestes ritornelos, tendo a repetição como descolamentos de rabiscos, traços que criam outras formas, mergulhamos nos padrões, para sermos capazes de reconhecê-los para nos libertarmos deles, como nos inspira Escher (1938), com sua obra "Céu e Água". 
Figura 1 - Céu e Água II - M. C. Escher (1938)

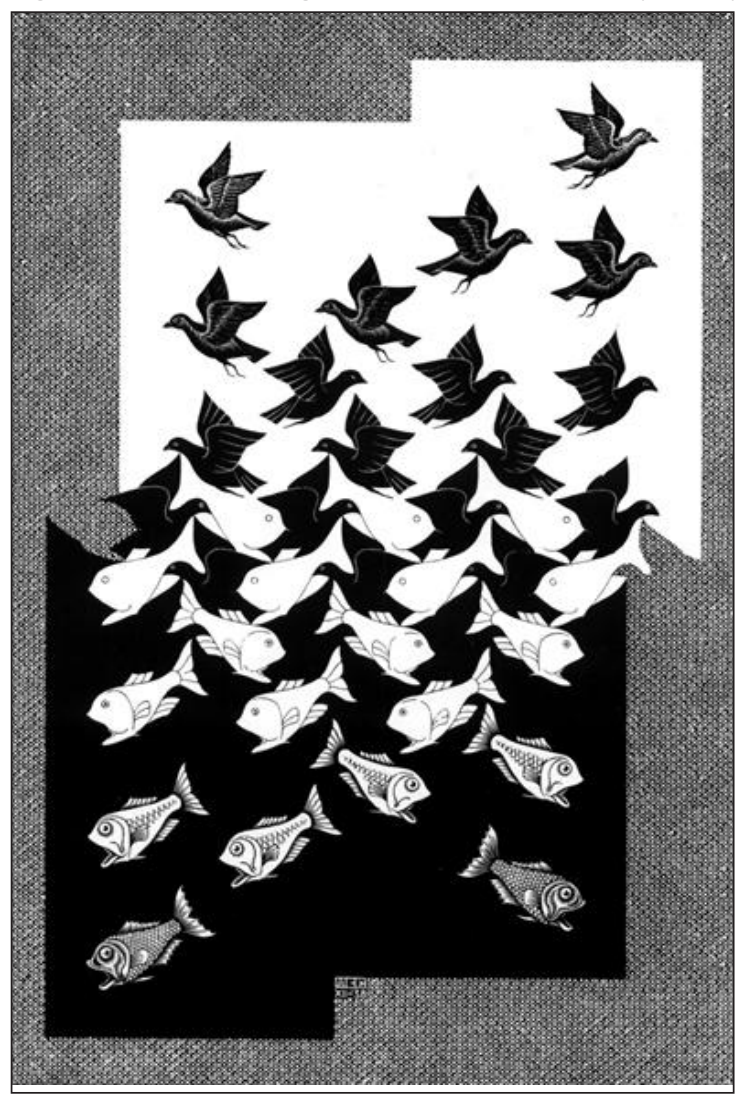

Fonte: http://mcescher.com/gallery/ transformation-prints/\#iLightbox[gallery_image_1]/5

Escher ${ }^{3}$ é um artista que mergulhou nos padrões, reterritorializou-se, e sua obra revela, nos ritornelos, repetições rítmicas, uma aparente ilusão de aprisionamento, que na individuação da forma vai ganhando outras proporções, desterritorializando-se de si mesma, num movimento nômade, se perder de si, como um lugar fixo. 
Ao mesmo tempo absorto nos padrões, sobretudo desta obra, influenciada pela arte islâmica, por estudos geométricos e pelas narrativas contadas em azulejos, o artista rompe com o previsível. O aprisionamento destes padrões matematicamente calculados se desdobra em liberdade. Ainda que exista um padrão que se funde na criação, é um uso de apropriação da repetição do padrão para ganhar outra dimensão criativa. A essa dimensão, percebemos, sentimos como arte.

A arte é a linguagem das sensações, que faz entrar nas palavras, nas cores, nos sons ou nas pedras. A arte desfaz a tríplice organização das percepções, afecções e opiniões, que substitui por um monumento composto de perceptos, de afectos e de blocos de sensações que fazem as vezes de linguagem. (DELEUZE; GUATTARI, 1993, p. 228).

Realidade-virtualidade e pensamento-acontecimento: as artes, em suas variadas apresentações, conduzem-nos a inúmeros agenciamentos e criação de realidades, ampliando nossas sensações, percepções e atuação no/com o mundo. Como "máquinas de guerra do pensamento nômade" (DELEUZE; GUATTARI, 2012) que respondem a outras regras, condutas e linguagens, e que questionam e contrariam qualquer hierarquia, "movimentos de desterritorialização" e "linhas de fuga" (DELEUZE; GUATTARI, 1983) tornam-se possíveis pela criação e pelo uso (CERTEAU, 2014) das artes e dos artefatos culturais nos "espaçostempos" escolares e, também, fora deles; e, quando capturados pelos "processos de reterritorialização", manifestam outras buscas.

A ideia de Deleuze e Guattari (2012, p. 53) acerca do nomadismo pode ser entendido como aquele que, apesar de ter trajetos e rotas costumeiras, que vão de um ponto a outro com uma certa constância e velocidade, esses pontos não são delimitantes ou sempre previsíveis. Eles sabem esperar e utilizam a "pausa como processo" dos movimentos de seus corpos que se distribuem em espaços abertos, indefinidos, lisos e fluidos.

Apesar de seus caminhos estarem predeterminados por pontos, eles só existem para serem abandonados. Por isso, a vida nômade se localiza no intermezzo entre consistência, autonomia, direções próprias e espaços não comunicantes, "[...] marcados apenas por traços que se apagam e se deslocam com o trajeto" (DELEUZE; GUATTARI, 2012, p. 55).

É nesse sentido que o nômade não tem pontos, trajetos, nem terra, embora evidentemente o tenha. [...] Para o nômade, é a desterritorialização 
que constitui sua ligação com a terra, por isso ele se reterritorializa na sua própria desterritorialização. É a terra que desterritorializa ela mesma, de modo que o nômade aí encontra um território. A terra deixa de ser terra, e tende a devir simples solo ou suporte. (DELEUZE; GUATTARI, 2012, p. 56).

Desterritorializar é se despir, colocar os pés descalços em andanças (RANGEL; SANTOS, 2020). Perceber nos pés sua potência de deslocamento, sua força de sustentação de um corpo que se coloca em muitos devires ao criar outras trilhas. Compreender os momentos da caminhada e da espera, como tática. Pôr os pés para o alto, para fazer circular o sangue na veia que pulsa a potência da vontade de voltar a caminhar, para desassentar os conhecimentos assentados nos glúteos, mãos e cabeças colonizantes, como diz Rangel e Santos (2020, p. 60-2), e se posicionar para impulsionar e fazer acontecer outros saltos.

O movimento de desterritorializar é sair da zona de conforto, daquilo que é dado como condição ou verdade. É aceitar um terreiro ainda não experienciado, que está ali esperando o acaso e que é criado por meio do uso daquilo que está sendo agenciado em seus afetos. Memórias, gestos, passos firmes, passos largos, passos curtos, passos frágeis, corpos vívidos, em imanência, na criação de outros modos de vida, nos "fazeressaberes" com os possíveis Outros.

\section{CRIAÇÕES A PARTIR DE IMAGENS-MOVIMENTOS-SONS}

A arte entra nos processos educativos como um dispositivo anárquico, antidisciplinar, porém os modos de fazer ainda podem estar impregnados de padrões que os definem como certos ou verdadeiros. Mas, ainda assim, na potência do falso, como brincadeiras nas fabulações que vamos criando enquanto realidades, a maneira de como criamos nossas peças de arte, seja o podcast, sejam livros, cartões-postais, vídeos, reflete os nossos usos, tanto dos clichês quanto dos artefatos enquanto linguagem e tecnologias, na tessitura de "conhecimentossignificações".

Em uma experiência desenvolvida com as turmas de pedagogia através da disciplina Pesquisa e Prática Pedagógica (PPP) com a professora Nilda Alves ${ }^{4}$, estudantes são mobilizados a "verouvirsentirpensar" por meio do audiovisual, entendendo este como artefato e linguagem artística mobilizadora de pesquisa. E, para compreendermos as capturas que as imagens e os sons nos causam pelos

\footnotetext{
${ }^{4}$ Coordenadora da pesquisa e do GrPesq Currículos Cotidianos, Redes Educativas, Imagens e Sons.
} 
clichês, fazemos uso da arte do cinema, com a metodologia das "cineconversas", em que, ao assistir juntos aos filmes e conversarmos acerca deles, buscamos o entendimento de sentimentos, sensações e pensamentos nas relações cotidianas, as quais, muitas vezes, não nos damos conta, por estarmos muito próximas a elas.

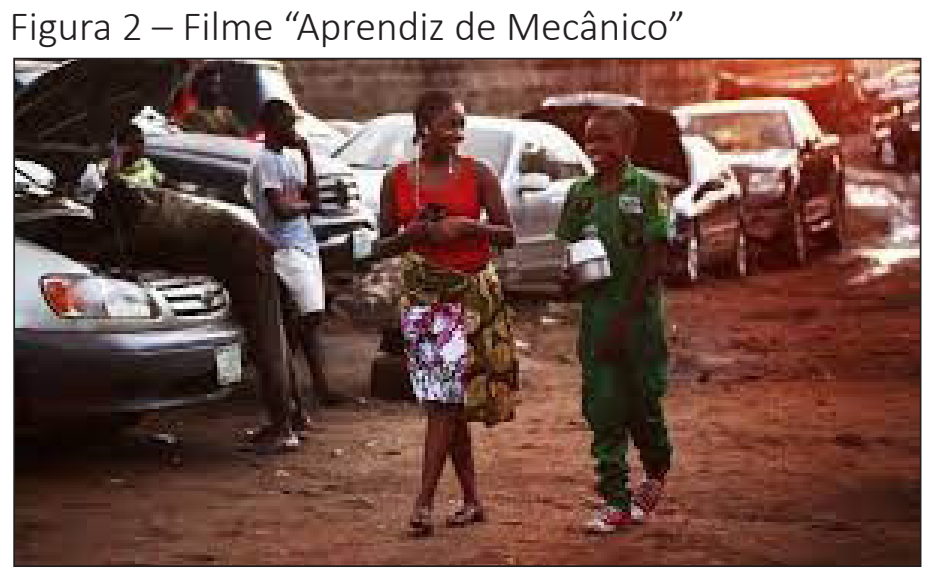

Fonte: http://youtube.com/watch?v=Lu1i5ZS78J4\&t=569s

Nas "cineconversas", caminhamos percebendo como as "praticantespensantes" se identificam com as narrativas, seja pela história contada, seja pelas imagens, ambiências sonoras e seus clichês. O filme como arte cria pontes e hiatos com as emoções e as memórias que despertam das narrativas. Ainda que as lembranças não sejam exatamente aquelas vivenciadas, elas tornam-se narrativas criadas a partir das experimentações sensoriais e emocionais, que acessam sentimentos que se revelam ou recriam vivências, situações disparadas pelo filme.

Também foi possível mostrar outras possibilidades de usos de diferentes artefatos no processo da pesquisa, apropriando-nos de metodologias que fazem do audiovisual uma potência, quando em seus usos, seja "vendoouvindosentidopensados" os filmes, ou produzindo seus próprios filmes, possibilitam outros enredamentos na percepção da criação de narrativas em outras realidades com as manipulações de artefatos - dispositivos tecnológicos, os sentimentos, as emoções, os pensamentos e a linguagem.

Os filmes "vistosouvidossentidospensados" são agenciamentos que revelam empatias nas criações das realidades dos estudantes. Esses agenciamentos se dão 
pelas questões ordinárias, na mobilização das emoções, que permeiam a fronteira entre o ambiente de onde parte e para onde vai, impregnado de frustrações, sonhos e criações. Os modos de viver são latentes, como estar numa universidade pública, chegar a esta universidade depois de uma jornada de trabalho, viver o enfrentamento da violência urbana - tráfico, milícia, polícia, situações de moradia, preconceitos raciais, religiosos, entre pessoas de diferentes fronteiras territoriais, culturais e sociais.

Identificamos, nestas conversas com os filmes, que usamos os clichês para nos defender da ideia de uma suposta realidade dura, difícil, em que, sobretudo as imagens e os sons dos filmes, ao nos capturar, nos dão um suporte imaginário na fantasia dos clichês, mesmo que seja naquilo que é previsível, pois nos coloca diante de um ambiente possível, na ideia de um final feliz. Por identificação com os personagens, sejam os vilões, sejam os heróis, mocinhos ou bandidos, quase sempre numa ideia dicotômica, encontramos imagens de força que, embaladas por ambiências sonoras, nos remetem a arquétipos, para acreditar numa possível forra.

Segundo Guéron (2011), estudioso da obra de Deleuze, os clichês são um esquema de reação afetivo-emocional, que nos causam sensações corpóreas, mesmo sabendo que somos levados a situações já esperadas. Essas sensações mobilizantes, muitas vezes, são recorrentes de experiências acessadas num imaginário que produzimos, independentemente da linguagem, dos suportes pelas quais circulam nos nossos cotidianos. Ao nos colocarmos num posicionamento de defesa nas nossas realidades, que também são criadas por nós em clichês, levam-nos ao comportamento dos próprios clichês, nas fabulações cotidianas. Deleuze (1983) nos envolve nessa trama como clichês anônimos, no deslocamento de emoções e criadores de crenças.

São estas imagens flutuantes, estes clichês anônimos que circulam no mundo exterior, mas também que penetram em cada um e constituem seu mundo interior, de modo tal que cada um só possui clichês psíquicos dentro de si, através dos quais pensa e sente, sendo ele próprio um clichê entre os outros no mundo que o cerca. Clichês físicos, óticos e sonoros, e clichês psíquicos se alimentam mutuamente. Para que as pessoas se suportem a si mesmas e ao mundo, é preciso que a miséria tenha tomado o interior das consciências e que o interior seja como o exterior. [...] Como não acreditar numa poderosa organização intencional, num grande e poderoso complô, que encontrou o modo de fazer os clichês circularem de fora para dentro e de dentro pra fora? (DELEUZE, 1983, p. 256-7). 
O clichê pode ser um dispositivo que escancara uma ação, revela a padronização de nuances de vozes, gestos, enquadramentos, sensações e pensamentos que o faz potente na virtualidade com a criação de um imaginário moral, que vai dando forma à vida ordinária.

[...] chegaremos então a uma definição de clichê como uma espécie de imagem-lei, de imagem-moral, que age como um mecanismo padronizador e determinador de valor, e veremos o cinema num jogo de criá-las e reconstruí-las. Um jogo, portanto, em que o cinema tanto se afirma como um dispositivo de poder que limita e esvazia o pensamento, enquanto se afirma como uma notável potência do pensamento na medida em que nos ajuda a identificar os problemas da realidade e da vida e produzir novas possibilidades para estas. (GUÉRON, 2011, p. 14).

O clichê deixa marcas, registros que vão compondo um receituário, e fazemos usos deles, quando lançamos mão dos dispositivos tecnológicos para criação dos materiais que vislumbramos ter potencialidades artísticas, como podcasts, filmetes, livros, pois acabamos reproduzindo o que está numa fôrma hegemônica.

Num segundo momento, depois de conversar com os filmes, propomos que as estudantes do curso de Formação de Professoras produzissem seu próprio filme; para isso, realizamos uma oficina de criação audiovisual, envolvendo produção, gravação e edição de dois filmetes.

Pesquisa e Prática Pedagógica (PPP) é um componente curricular que envolve a metodologia de pesquisa. Ao realizar as oficinas de vídeo, sugerimos outro modo de fazer pesquisa, com o uso da linguagem audiovisual, e desenvolver maneiras de apropriação de artefatos e dispositivos tecnológicos digitais, como os celulares, computadores, câmeras de vídeo, microfones, softwares de edição de imagens e sons, como artefatos pedagógicos e curriculares.

As conversas com essa turma trouxeram intimidades, jeitos particulares de "fazeressaberes" acerca da comida no seu processo de socialização, em que sofrem mudanças de acomodação e de criação de um outro modo de fazer. Quando um prato como o cuscuz que é feito de diferentes formas, dependendo da região do país, revela as particularidades desses usos, que, muitas vezes, estão relacionados com as ofertas dos produtos, clima e os modos singulares de fazer. Isso mostra, dentro do processo educativo, que não há uma verdade absoluta, o certo e o errado, e sim modos de apropriação e criação, a partir do que é disponível e o quanto estamos disponíveis a estes acontecimentos. 
A comida, ao revelar os modos de existir, revela também estranhezas, preconceitos, hábitos circunscritos pela história de uma sociedade que traz marcas colonialistas e escravocratas, numa tentativa de apagamento das culturas. A culinárias nas suas diferenças se impregnam de uma ideia exótica, como um movimento de sobrevivência dos aspectos culturais que as mantêm como força estética-política. Quando acontecem os encontros, as conversas, as manifestações artísticas que giram em torno da comida passam a ser criações. Trouxemos essa conversa para a produção audiovisual.

A produção coletiva dos filmetes evidencia as táticas nos modos dos "fazeressaberes" possíveis com usos das tecnologias disponíveis nos cotidianos, com as possibilidades de conversas que trazem elementos curriculares presentes nas escolas. Essas experiências de produção de narrativas "imagéticassonoras" com "discentesdocentes" criam ambientes de sensibilização, com múltiplas potências de criação individual e coletiva num hibridismo; de ética e estética - que afirmam possibilidades múltiplas de "ser professora e professor" que estão em constante criação com os estudantes. Produzimos dois filmetes de um minuto cada um: um tratando das questões culturais por meio da arte, e outro por meio da comida.

A narrativa acerca da comida como pano de fundo para as questões da criação de outros modos de existir traz como prato principal o cuscuz nordestino, que metamorfoseia sua receita em diferentes regiões brasileiras. Cada região se apropriou de artefatos, como utensílios, alimentos e os jeitos de fazer que trazem as marcas de diferentes sabores e saberes ao produzir o cuscuz de milho e tapioca, doce e salgado.

Ao trazer as questões do nordeste, foram acessadas memórias, sensações das infâncias, da chegada ao Rio de Janeiro, dos encontros das tradições nas feiras e festas. Outra questão de relevância é o preconceito que existe em relação aos preparos dos pratos nordestinos. A estranheza aos alimentos que são utilizados, os jeitos e gestos nos preparos, abordando, assim, esses conflitos que são gerados em torno desses ingredientes e materiais.

O roteiro elaborado pelas estudantes mediadas pelas pesquisadoras do GrPesq conta a história de um casal paulista que vem ao Rio de Janeiro como turista e visita a feira de tradição nordestina, no bairro de São Cristóvão. O casal, ao chegar à feira, deslumbra-se com a cultura, artes feitas por artesãos, a música e a dança. No momento em que deseja fazer uma refeição, o casal, ao se depa- 
rar com os pratos nordestinos, como o sarapatel, por sua aparência, cria uma certa resistência em consumi-lo. Por fim, o casal escolhe um prato que tem uma aparência mais convidativa a eles, o cuscuz feito de milho; depois de comer, eles voltam a dançar.

A produção foi realizada pelas estudantes, que foram gravar e fotografar a ambiência da feira de tradição nordestina em São Cristóvão, capturando cenas de pessoas circulando pela feira, dançando, vendo os artesanatos, os alimentos. E uma câmera subjetiva fazia a intenção do casal, tendo reações diante dessas circulações. Posteriormente, estas cenas de reação foram interpretadas por uma dupla de estudantes, representando o casal das imagens subjetivas, e gravadas em estúdio (na sala de encontro do GRPesq - Laboratório de Educação e Imagens).

Figura 3 - Filme "Sarapatel"

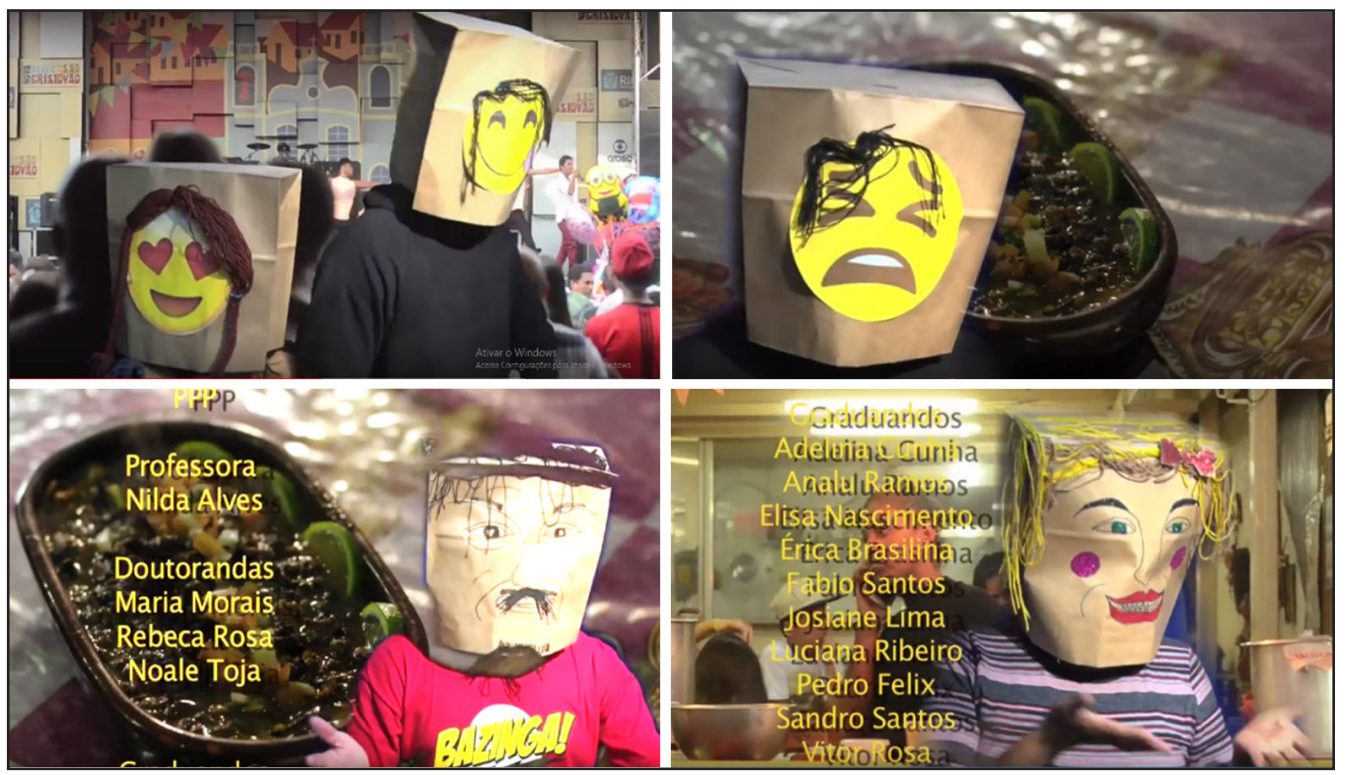

Fonte: Arquivo pessoal.

Nessa experiência, observamos as bricolagens com os usos de artefatos como sacolas de papel, transformando-se em máscaras com colagem de emojis capturados na Internet. Ela nos mostra também a nossa capacidade de criação de realidades, por meio de aparatos tecnológicos como a técnica do chroma key, recurso utilizado numa combinação no momento de gravação com o fundo infinito 
no tom azul, e na aderência de imagens que podem vir de um banco de imagens relacionadas ao tema, que são sobrepostas, no processo de edição.

Este efeito dá a ilusão de que a cena está acontecendo nos ambientes criados pelos cenários, fabulando outras realidades. Nesta metáfora, percebemos as potências de criação de cenários de realidades, que nos levam a um imaginário de outra dimensão, ao criar crenças acerca do que é "vistoouvido" como verdade. Estes "fazeressaberes" revelam a potência do falso nas fabulações intencionadas de emoções, sensibilidades e afetos. Os usos tecnológicos nos fazem criadores de situações inexistentes, mas possíveis, que se realizam pelas nossas astúcias, bricolagens e, sobretudo, pelo desejo de criação. Na virtualização, a criação audiovisual se atualiza, materializando outras dimensões de realidades.

Outra criação vivenciada por uma de nós com estudantes da rede pública da cidade do Rio de Janeiro traz a fotografia como artefato de criação, entendendo como as redes educativas ampliam-se, formando "redesdeconhecimentos" diversas que, sobretudo, foram alargadas desde o início da pandemia de covid-19, no ano de 2020.

A produção coletiva evidencia as táticas nos modos dos "fazeressaberes" possíveis com usos das tecnologias disponíveis nos cotidianos, com as possibilidades de conversas que trazem elementos curriculares presentes nas escolas. A partir dos usos de autorretratos captados por celulares em sala de aula, os estudantes fizeram uma releitura das obras do pintor, serígrafo e cineasta norte-americano Andy Warhol, um dos maiores representantes da Pop Art, movimento artístico e midiático que teve seu súbito aparecimento no início da década de 1960, no Reino Unido. Após muita conversa e observação de alguns trabalhos de Warhol, os estudantes foram convidados a fazerem uma manipulação de suas fotografias, utilizando um programa de edição de imagens que foi instalado nos notebooks fornecidos às escolas pela prefeitura, já que os aparelhos poderiam ser utilizados como artefatos didáticos em atividades realizadas nos "espaçostempos" escolares. 
Figura 4 - Trabalhos criados por estudantes da rede pública municipal do RJ

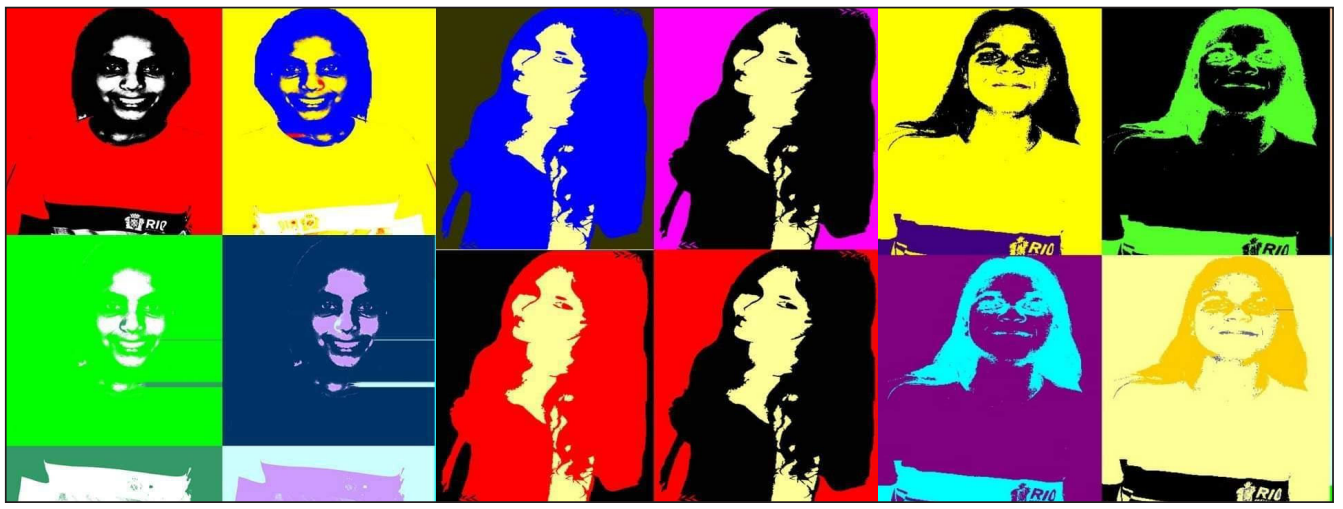

Fonte: Arquivo pessoal.

Numa experimentação inédita e com poucos recursos disponíveis - cinco notebooks para uma turma de quarenta alunos -, a criação dos trabalhos emergiu em torno de parcerias, auxílios e "aprendizagensensinos" mútuos. Fomos marcados por "práticasteorias" sensíveis e sensibilizadoras de novas formas de pensamentos e condutas.

A experiência de criação mobilizou uma sensibilização, com múltiplas potências - de criação individual e coletiva, num hibridismo; de ética e estética -, as quais afirmam possibilidades múltiplas de "ser professora e professor" que estão em constante criação com os estudantes. Quando "vemosouvimossentimos" os cotidianos através de imagens e sons, criamos possibilidades para entender como pesquisar com os cotidianos é ser atravessado por múltiplas redes educativas que nos formam e pelas quais somos formadas (ALVES, 2019, p. 115), criando versões de mundos temporários, polifônicos e instáveis.

Num fazer nômade de deslocamentos, experimentamos as possibilidades de usos das artes e de artefatos culturais e tecnológicos diversos, com a transformação de diferentes materiais e ambientes, propiciando a tessitura de inúmeros "conhecimentosignificações". Nesse contexto, trabalhamos as imagens fotográficas e as obras de arte como artefatos curriculares, propiciando diálogos éticos-estéticos-políticos no currículo e revelando a fotografia como uma tática de fruição, criação e comunicação.

Por último, trazemos uma experiência criativa em forma de relato e criação audiovisual vivenciada por uma de nós enquanto "discentedocente" na disciplina 
"Imagens e sons na contemporaneidade", ministrada por Nilda Alves e Leonardo Nolasco, no Programa de Pós-Graduação em Educação da Universidade do Estado do Rio de Janeiro (ProPEd-UERJ), no ano de 2021.

Foi através das interferências e dos ruídos dos corredores da escola, das conversas entre pessoas no ponto de ônibus, dos choros e sorrisos de meus filhos em casa, que ouvi as tantas conversas tecidas na disciplina. A cada encontro, pude me conectar às minhas vivências buscando memórias de infância, dos meus caminhos e escolhas, da minha prática com os "praticantespensantes", realizando mentalmente uma costura repleta de imagens e sons. Foi nesse movimento, meio que ziguezagueando entre pensamentos, textos, imagens e sons, que percebi o quanto ver filmes e ouvir e fazer podcast me forma tanto quanto os textos escritos.

Figura 5 - Home Office

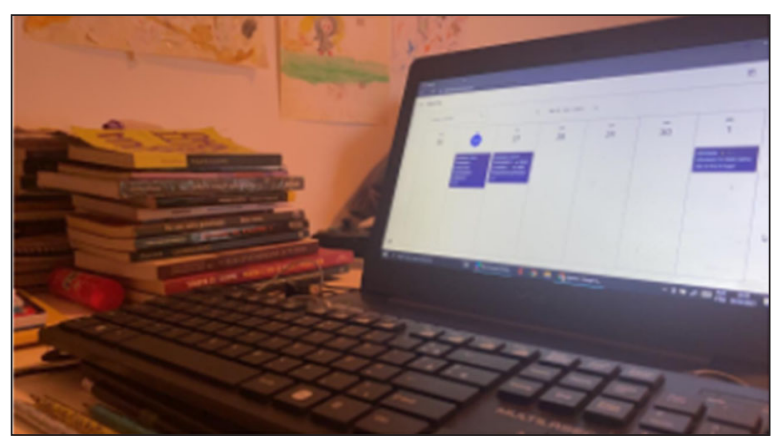

Fonte: Arquivo pessoal.

A partir desse emaranhado de criações trazidas em nossas conversas, filmes, textos, podcasts e outros, surgiu a criação de um curta-metragem, em parceria com uma amiga do grupo de pesquisa, inspirado nesse período pandêmico vivenciado desde 2020. Ainda com vagos pensamentos, esperando as peripécias dos acontecimentos para finalizar, o curta traz as andanças das criações docentes em meio a tanto caos e calamidade mundial. Dizendo, assim, ser possível criar, interagir e, sobretudo, estar afetivamente com o outro através da tela. 
Figura 6 - Contação de História a distância

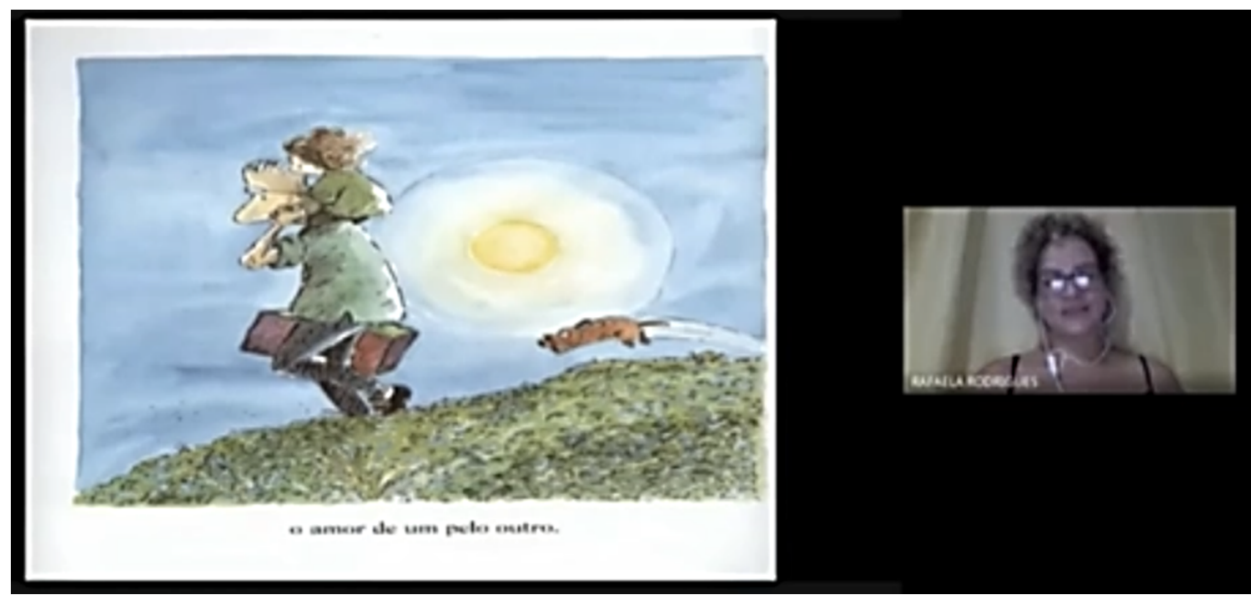

Fonte: Arquivo pessoal.

Nessas experimentações, percebemos como forjamos e criamos realidades e significações em "fazeressaberes" negociados em "práticasteorias" democráticas, lúdicas, que acessam sentimentos, sensações e emoções atravessados pela ética e pela estética, em que "discentesdocentes" são autoras e criadoras de seus conhecimentosignificações, aproximando as realidades "nosdoscom" os cotidianos às questões curriculares.

O uso das Artes foi um convite a eliminar a superfície do tecido acabado, puxar fios da trama coletiva, desfiando-os dessas linhas, e desterritorializar. Desterritorializar ao saborear "fazeressaberes" dos caminhos percorridos até aqui, criando narrativas nômades, migrantes, que se deslocam e se colocam na aventura de romper superfícies disciplinadas, fronteiriças, ao encontrar e reconhecer o Outro, como potência da vontade de criar.

\section{REFERÊNCIAS}

ALVES, Nilda. Sobre as redes educativas que formamos e que nos formam. In: ALVES, Nilda. Práticas pedagógicas em imagens e narrativas: memórias de processos didáticos e curriculares para pensar as escolas hoje. São Paulo: Cortez, 2019. p. 115-33.

CERTEAU, Michel. A invenção do cotidiano - artes do fazer. Petrópolis: Vozes, 2014. 
DELEUZE, Gilles; GUATTARI, Félix. Mil platôs: capitalismo e esquizofrenia. Tradução de Aurélio Guerra Neto e Cecília Pinto Costa. Rio de Janeiro: Ed. 34, São Paulo, 2007. V. 1.

DELEUZE, Gilles. A imagem-movimento. Tradução de Stela Senra. São Paulo: Brasiliense, 1983. (Cinema 1).

DELEUZE, Gilles; GUATTARI, Felix. Tratado de nomadologia: a máquina de Guerra. In: DELEUZE, Gilles; GUATTARI, Felix. Mil platôs: capitalismo e esquizofrenia 2. São Paulo: Editora 34, 2012. V. 5.

DELEUZE, Gilles; GUATTARI, Felix. O que é Filosofia? São Paulo: Ed. 34, 1993.

GUÉRON, Rodrigo. Da imagem ao clichê, do clichê à imagem: Deleuze, cinema e pensamento. Editora Nau: Rio de Janeiro, 2011.

MACHADO, Arlindo. O quarto iconoclasmo e outros ensaios hereges. Rio de Janeiro: Rios Ambiciosos, 2001.

RANGEL, Leonardo; SANTOS, Edméa. O caminhar na educação: narrativas de aprendizagens, pesquisa e formação. Editora Atena: Paraná, 2020.

\section{Sobre as autoras:}

Noale Toja: Doutora em Educação e Cotidianos pela Universidade do Estado do Rio de Janeiro (ProPEd/UERJ). Mestre em Educação, Comunicação, Cultura e Periferias pela UERJ. Participante do GRPesq Currículos e Cotidianos: Redes Educativas, Imagens e Sons, na linha de pesquisa "Cotidianos, Redes Educativas e Processos Culturais". Colabora em projetos de Educomunicação na articulação da educação, comunicação, artes e tecnologias. E-mail: noaletoja22@gmail.com, Orcid: https://orcid.org/0000-0002-1207-2795

Rafaela Rodrigues da Conceição: Doutoranda em Educação pela Universidade do Estado do Rio de Janeiro (UERJ). Mestre em Educação pela Universidade Federal Rural do Rio de Janeiro (UFRRJ). Pedagoga pela UFRRJ. Atua como docente dos Anos Iniciais do Ensino Fundamental na rede particular de ensino e no Colégio Pedro II. Integrante do GrPesq Currículos Cotidianos: Redes Educativas, Imagens e Sons, da Universidade Estadual do Rio de Janeiro (UERJ). E-mail: prof.rafaelarodrigues@gmail.com, Orcid:https://orcid.org/0000-0003-2905-6043 
Talita Malheiros: Mestranda em Educação na Universidade do Estado do Rio de Janeiro (UERJ). Especialista em Arte, Educação e Tecnologias Contemporâneas pela Universidade de Brasília (UnB). Professora de Artes Visuais da Educação Básica (SME/RJ). Integrante do GrPesq Currículos Cotidianos: Redes Educativas, Imagens e Sons, da UERJ. E-mail: tatamalheiros@yahoo.com.br, Orcid: https://orcid.org/0000-0001-9672-1862

Recebido em: 10/09/2021

Aprovado em: 13/10/2021 